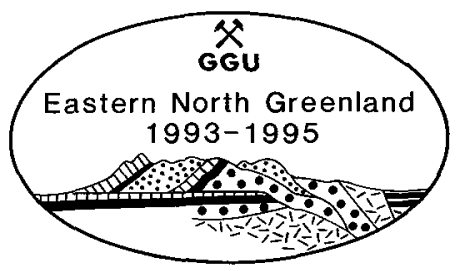

\title{
The geology of the north-eastern corner of Greenland - photogeological studies and 1993 field work
}

\author{
H. F. Jepsen, J. C. Escher, J. D. Friderichsen and A. K. \\ Higgins
}

\begin{abstract}
Late Archaean and Early Proterozoic crust-forming events in North-East and eastern North Greenland were succeeded by Middle Proterozoic sedimentation and volcanic activity; Late Proterozoic through Tertiary sedimentation was interrupted by several periods of tectonic activity, including the Caledonian orogeny in East Greenland and the Mesozoic deformation of the Wandel Hav mobile belt. Photogeological studies helped pinpoint areas of special interest which were investigated during the short 1993 field season. Insights gained during field work include: the nature of the crystalline basement terrain in the Caledonian fold belt, redefinition of the upper boundary of the Upper Proterozoic Rivieradal sandstones, revision of Caledonian nappe terminology, and the northern extension of the Caledonian Storstrømmen shear zone.
\end{abstract}

H. F. J., J. C. E., J. D. F. \& A. K. H., Geological Survey of Greenland, Øster Voldgade 10, DK-1350 Copenhagen K, Denmark.

Reconnaissance field work carried out in 1993 in North-East and eastern North Greenland marked the initial stage of a new 1:500 000 mapping project (map sheet 9; Henriksen, 1994) aimed at investigation of the region between Jökelbugten $\left(78^{\circ} \mathrm{N}\right)$ and northern Kronprins Christian Land $\left(81^{\circ} \mathrm{N}\right)$ (Fig. 1). The main programme of field work will be carried out in 1994 and 1995 (Henriksen, 1994).

The region of study includes the northern part of the East Greenland Caledonides, and is dominated by rock units and geological problems which were encountered during earlier 1:500 000 mapping projects to the north (map sheet 8; Henriksen, 1992) and south (map sheet 10). Prior to the 1993 summer photogeological studies were made in the Survey's photogeological laboratory on the basis of 1:150 000 vertical aerial photographs using standard survey techniques (Hougaard et al., 1991). A set of new 1:100 000 topographic maps was prepared at the same time, using the same aerial photographs and ground control points established by Kort- og Matrikelstyrelsen (National Survey and Cadastre). Geological interpretations, in part based on earlier work in the region, were compiled onto 16 preliminary geological maps at 1:100 000 and two summary sheets at 1:250 000 .

This article reviews the geological evolution of the north-eastern corner of Greenland, and presents preliminary results of photogeological studies and 1993 field work.

\section{Geological framework}

North-East and eastern North Greenland are located at the north-east corner of the Canada-Greenland Precambrian shield, and the geological evolution of the region since the Early Proterozoic reflects this location. The shield area has acted as a stable basement since the Middle Proterozoic, upon which continental and marine shelf sediments and volcanic rocks were deposited. The marginal areas to the east and north have been the sites of repeated cycles of orogenic activity and sedimentation; these include accretion of Early Proterozoic crust, Middle Proterozoic sedimentation and volcanism, Late Proterozoic - Lower Palaeozoic sedimentation and Palaeozoic orogenesis (Ellesmerian orogeny in North Greenland, Caledonian orogeny in East Greenland), Late Palaeozoic Tertiary sedimentation, and Mesozoic to Early Tertiary strike-slip deformation (Figs 1, 2).

\section{Archaean - Lower Proterozoic crystalline basement}

Crystalline basement rocks are widespread south of Lambert Land, and also occur in eastern and central Lambert Land and eastern coastal areas of Kronprins Christian Land (Fig. 1). In central Lambert Land they are in thrust contact against Independence Fjord Group sandstones. They represent the northward extension of the 


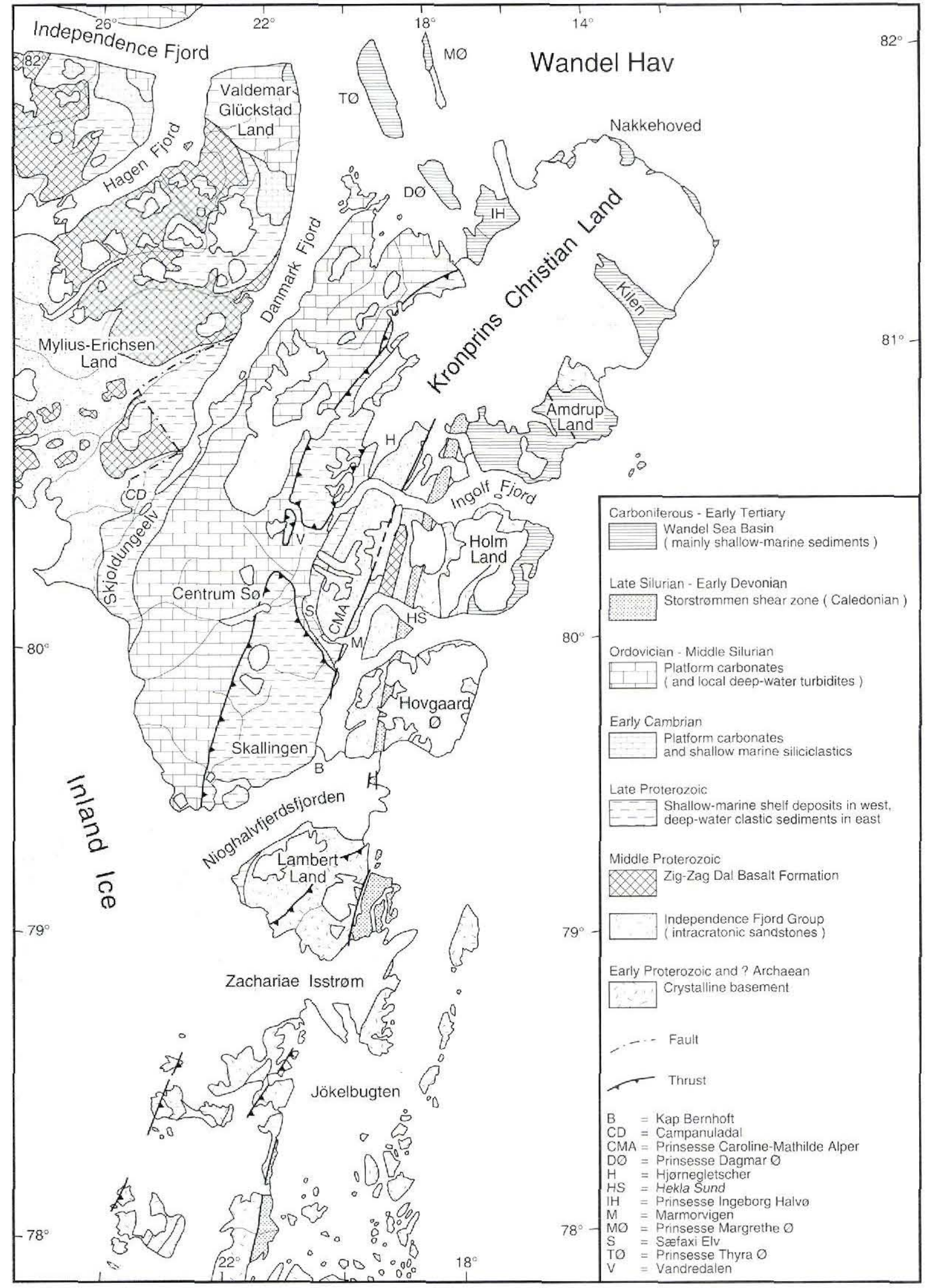

Fig. 1. Geological map of North-East and eastern North Greenland from $78^{\circ}-82^{\circ} \mathrm{N}$, with place names mentioned in the text. 
gneiss complexes of the Dove Bugt - Germania Land region south of latitude $78^{\circ} \mathrm{N}$, and are assumed to have a similar make-up and geological history. $\mathrm{Rb}-\mathrm{Sr}$ and Sm-Nd model ages in the Dove Bugt - Germania Land region show that the dominant orthogneisses were emplaced during a Lower Proterozoic event of crustal formation about $2000 \mathrm{Ma}$ ago (Kalsbeek et al., 1993), while Archaean rocks have a restricted distribution (e.g. Steiger et al., 1976). Evidence of a Grenville (c. $1000 \mathrm{Ma}$ ) orogenic event is sparse, and currently limited to SHRIMP studies of zircon grains in metasedimentary sequences south of latitude $76^{\circ} \mathrm{N}$ (A. P. Nutman, personal communication, 1993). ${ }^{40} \mathrm{Ar}-{ }^{39} \mathrm{Ar}$ mineral ages demonstrate that the basement gneisses have everywhere suffered Caledonian metamorphism (Dallmeyer et al., 1994), and much of the deformation pattern preserved in the gneisses is believed to be Caledonian (e.g. Chadwick \& Friend, 1991; Strachan et al., 1992). A notable feature of Germania Land is the presence of eclogites (Gilotti, 1993), thought to be Caledonian, but it is uncertain whether this eclogite province extends north of latitude $78^{\circ} \mathrm{N}$.

Little attention has been paid to the crystalline terrain of the region $78^{\circ}-81^{\circ} \mathrm{N}$ by previous workers, apart from the aerial reconnaissance observations and photographic interpretations embodied in the structural and geological maps of Haller $(1971,1983)$. The only isotopic data from the crystalline terrain of the Caledonides in this region comprise a K-Ar age of $405 \mathrm{Ma}$ for a gneiss sample from eastern Lambert Land (Haller \& Kulp, 1962) and a multigrain zircon $\mathrm{U}-\mathrm{Pb}$ study on orthogneisses from Ingolf Fjord; the latter yielded an upper intercept age of 1960 $\mathrm{Ma}$ and a lower intercept age of $415 \mathrm{Ma}$ (R. T. Pidgeon, personal communication, 1982).

Crystalline basement rocks do not crop out in the foreland to the Caledonian fold belt west of Danmark Fjord. Indications of the possible age of the basement rocks at depth in this region, or hidden below the Inland Ice to the south, are indirect and from areas some distance away. $\mathrm{Rb}-\mathrm{Sr}$ whole rock isotope data on a giant orthogneiss inclusion in a dolerite dyke at Sydpasset $\left(82^{\circ} 13^{\prime} \mathrm{N}\right.$, $36^{\circ} 11^{\prime} \mathrm{W}$ ), and on ice transported gneiss and granite boulders from near the head of Independence Fjord $\left(81^{\circ} 56^{\prime} \mathrm{N}, 31^{\circ} 52^{\prime} \mathrm{W}\right)$, both yielded poorly defined Archaean ages (c. $2700 \mathrm{Ma})$ and indications of a later Early Proterozoic metamorphic event (Kalsbeek \& Jepsen, 1980).

Photogeological interpretation of the Jökelbugten Lambert Land region revealed dominant NNE-SSW foliation trends in the basement gneiss complexes, cut in some areas by NW-SE trending joint-like lineaments. Fold patterns were only distinguished in a few areas, and there were very few conspicuous mappable units such as major granite bodies or thick amphibolite units. The most prominent structural feature is a broad linear NNE-SSW trending belt traceable throughout the region, which clearly represents the northward extension of the Caledonian Storstrømmen shear zone (Strachan et al., 1992).

\section{Middle Proterozoic sedimentation and volcanism}

The crystalline basement rocks are overlain unconformably by a thick sequence of mainly non-marine clastic sediments of the Independence Fjord Group (Collinson, 1980) which record a period of intracratonic sag sedimentation (Sønderholm \& Jepsen, 1991). This was succeeded by a major episode of basic volcanism at about $1230 \mathrm{Ma}$, which led to eruption of the Zig-Zag Dal Basalt Formation and emplacement of numerous basic intrusions known as the Midsommersø Dolerites (Kalsbeek \& Jepsen, 1983, 1984). This volcanic event may be associated with rifting related to the initial opening of the 'Poseidon Ocean' along the northern margin of the Canadian-Greenland shield (Jackson \& Ianelli, 1981).

Both the sedimentary and volcanic sequences are widely distributed in North and North-East Greenland (Figs 1,2). Within the map sheet area (sheet $9,78^{\circ}-81^{\circ} \mathrm{N}$; Henriksen, 1994), flat lying sequences occur in the Caledonian foreland region west of Danmark Fjord, and further outcrops variably folded and metamorphosed crop out in Caledonian thrust sheets in a NNE-SSW trending zone up to $60 \mathrm{~km}$ wide and more than $300 \mathrm{~km}$ long (Fig. 1). The broad outlines of distribution of the Independence Fjord Group sandstones are clear on Haller's (1983) map, although they appear there under the now outdated 'Thule Group' designation.

On aerial photographs the pale coloured, massive Independence Fjord Group sandstones dissected by a network of black Midsommers $\emptyset$ Dolerites are easily recognised in both foreland areas and in Caledonian deformed areas. Boundaries with adjacent rock units can be mapped and the outcrop of the major intrusive bodies can be delimited; however, it is usually impossible to distinguish dykes from sills.

In the foreland areas west of Danmark Fjord, the dark coloured Zig-Zag Dal Basalt Formation is mappable as a unit on aerial photographs overlying the pale coloured Independence Fjord Group sandstones; locally the internal stratigraphy of the basalts can be outlined. In the alpine area of Kronprins Christian Land basalt units can only be distinguished in parts of the Prinsesse CarolineMathilde Alper and on Hovgaard $\emptyset$; because of strong deformation, basalts and intrusive bodies often cannot be separated photogeologically. 


\section{Late Proterozoic sedimentation}

The upper boundary of the Middle Proterozoic succession is a profound unconformity upon which the Late Proterozoic Hagen Fjord Group was deposited about 850-650 Ma ago. The Hagen Fjord Group comprises up to $1000 \mathrm{~m}$ of shallow marine sediments (Clemmensen \& Jepsen, 1992), and is well exposed in foreland areas around the head of Danmark Fjord. Several of the distinctive formations of the Hagen Fjord Group also occur in Caledonian nappe units of Kronprins Christian Land, where they overlie the partly equivalent deposits referred to the more than $2500 \mathrm{~m}$ thick Rivieradal sandstones (Hurst \& McKerrow, 1981).

Around Danmark Fjord, where the stratification is subhorizontal, individual formations of the Hagen Fjord Group are readily mappable on aerial photographs. This is particularly the case with the very distinctive, pale coloured, cliff-forming dolomites of the Fyns S $\varnothing$ Formation which overlie the much darker Kap Bernhard Formation. The uppermost unit of the group, the Kap Holbæk Formation, can be traced overlying the Fyns Sø Formation for a distance of more than $75 \mathrm{~km}$ along the east side of Danmark Fjord. In eastern Kronprins Christian Land, where the Hagen Fjord Group is found in several nappe units, only the light coloured Fyns Sø Formation is sufficiently distinctive to be depicted on the photogeological maps, except in areas where there is ground control from earlier field work (Fränkl, 1954, 1955; Hurst \& McKerrow, 1981; Peel et al., 1981).

The Rivieradal sandstones, only known in nappe units underlying other Hagen Fjord Group formations, form a mainly recessive unit on aerial photographs and lithological differences are not distinctive. Bedding plane traces in better exposed areas locally outline fold structures, and south of Centrum $S \varnothing$ a major fold pair can be traced over a zone $8 \mathrm{~km}$ wide and $20 \mathrm{~km}$ long.

\section{Lower Palaeozoic sedimentation}

In eastern North Greenland the Early-Middle Ordovician Wandel Valley Formation (Peel \& Smith, 1988) directly overlies the Hagen Fjord Group. Regional uplift at the beginning of the Ordovician, perhaps related to the early stages of Caledonian collision in the east, resulted in erosion of an unknown thickness of Cambrian strata and perhaps also the uppermost part of the Hagen Fjord Group. The Lower Palaeozoic carbonate platform succession is more completely preserved in western and central North Greenland (Higgins et al., 1991), but in eastern North Greenland is restricted to the Middle Ordovician Lower Silurian Wandel Valley, Sjællands Fjelde, Børglum River and Tures $\varnothing$ Formations, together with the car- bonate reef mounds of the Samuelsen Høj Formation (Fig. 2). The outcrop of these formations in much of Kronprins Christian Land was determined during the 1978-80 phase of the North Greenland expeditions (Henriksen, 1992). However, photogeological studies enable some formation boundaries to be extended into the poorly exposed and previously unmapped areas of southern Kronprins Christian Land.

Lower Palaeozoic carbonates are unknown in the present outcrop of the major Caledonian nappes in Kronprins Christian Land apart from the enigmatic Harefjeld Formation, and are almost restricted to the region west of the main nappe front (Fig. 1). However, over most of their outcrop they are affected by folding and minor westward thrust displacements of thin-skinned character.

Erosion of the rising Caledonian mountain chain produced vast amounts of detritus, which during the Silurian infilled the deep water trough of the Franklinian basin of North Greenland with several kilometres of turbidites (Hurst et al., 1983). Local outcrops of these Silurian turbidites (Lauge Koch Land Formation) occur in central Kronprins Christian Land overlying the platform carbonates.

\section{Caledonian deformation}

Kronprins Christian Land is the only area where the marginal zone of the Caledonian fold belt is well preserved, and where a transition can be traced from a pile of Caledonian thrust sheets and nappe units in the east, through a zone of folded platform strata disturbed by minor thrusts with thin-skinned geometry, into undisturbed foreland strata west of Danmark Fjord. South of Kronprins Christian Land erosion has exposed deeper levels of the Caledonian fold belt, and much of the marginal thrust zone is concealed beneath the Inland Ice. The presence of major thrust sheets in central Kronprins Christian Land was established by Fränkl $(1954,1955)$. Subsequent work over a wider area led Hurst \& McKerrow $(1981,1985)$ to distinguish three major thrust sheets in Kronprins Christian Land (the Sæfaxi Elv, Vandredalen and Finderup Land nappes), which they speculate were derived from areas upwards of $100 \mathrm{~km}$ to the east.

Photogeological studies cannot in general distinguish between Caledonian and older fold structures in the crystalline terrain south of Lambert Land. In most of Kronprins Christian Land, by contrast, Caledonian fold patterns and thrust boundaries are traceable in many areas in Proterozoic and Lower Palaeozoic strata; extrapolations can readily be made from areas where earlier workers have established boundaries in the field into unmapped areas.

One major Caledonian tectonic feature, a NNE-SSW 

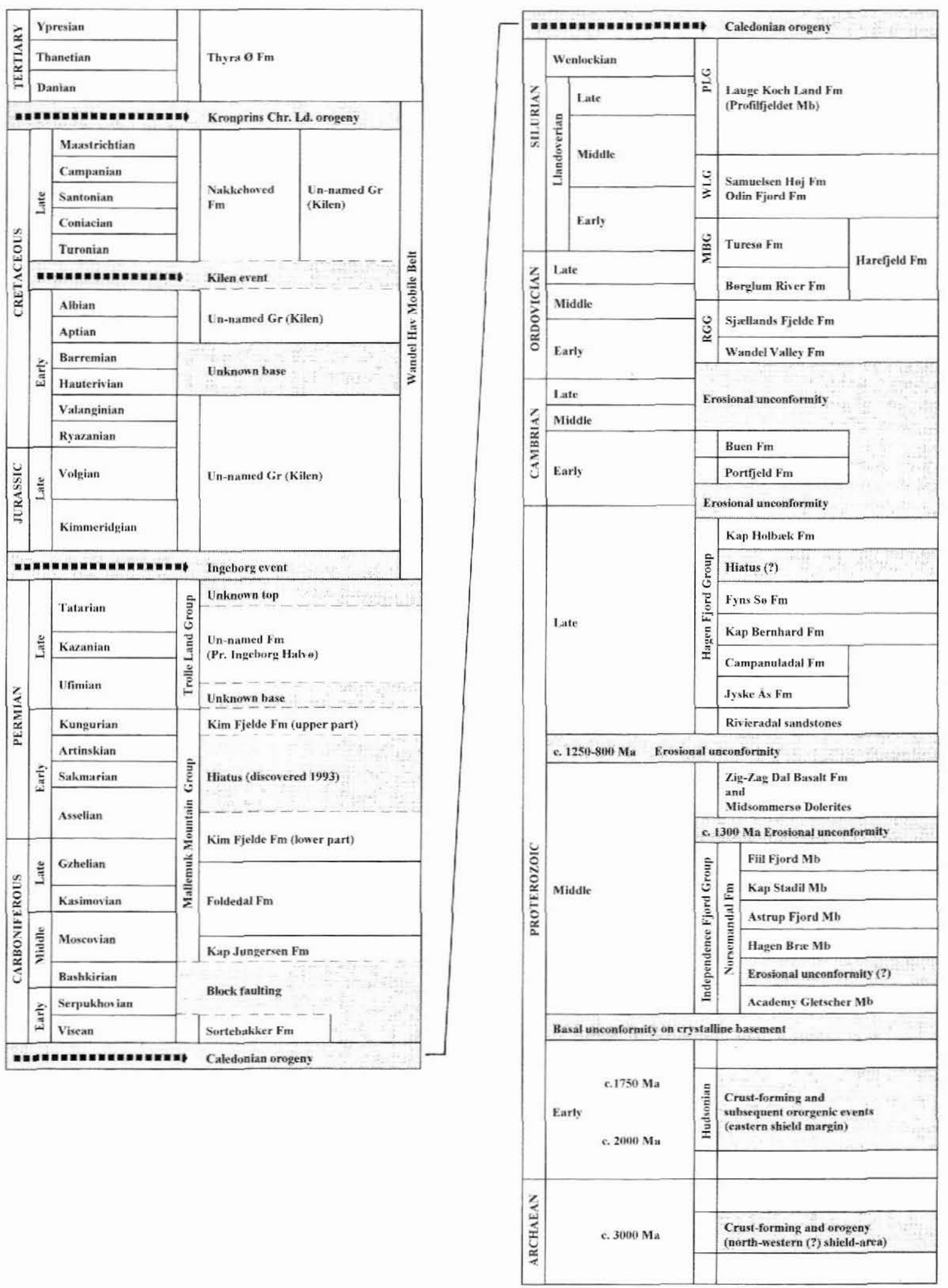

Fig. 2. Scheme showing principal events and lithostratigraphical divisions represented in the north-eastern corner of Greenland. PLG: Peary Land Group: WLG: Wulff Land Group: MBG: Morris Bugt Group; RGG: Ryder Gletscher Group. 
trending linear belt, can be traced on aerial photographs throughout the region $78^{\circ}-81^{\circ} \mathrm{N}$ (Fig. 1). In the southern part of this region it is developed in crystalline basement rocks, and follows the coast on the west side of Jökelbugten, continuing beneath Zachariae Isstrøm to cross eastern Lambert Land. North of Nioghalvfjerdsfjorden the linear belt continues through Hovgaard $\emptyset$, Holm Land and into northern Kronprins Christian Land, in these areas marking the boundary between crystalline basement rocks to the east and Proterozoic sedimentary and volcanic rocks in thrust sheets to the west. This linear belt is clearly the northward continuation of the Storstrømmen shear zone, a major Caledonian structure defined in the Dronning Louise Land - Hertugen af Orléans Land region $\left(76^{\circ}-78^{\circ} \mathrm{N}\right)$ (Strachan et al., 1992). Thus, before the 1993 field season it was known that this feature was at least $500 \mathrm{~km}$ in length.

\section{Upper Palaeozoic sedimentation}

Towards the end of the Silurian an Amerasian supercontinent was formed and eastern North Greenland, in the middle of that continent, was an area of continued crustal unrest between the Middle Devonian and Early Permian (Håkansson \& Stemmerik, 1989). Block-faulting, strikeslip faulting and initial rifting parallel to the Caledonian and Ellesmerian orogenic trends resulted in formation of two separate basins, the North Greenland - Svalbard rift basin and the East Greenland - West Norway rift basin (fig. 1 in Stemmerik \& Håkansson, 1989); the successions were collectively grouped together as the Wandel Sea basin by Dawes \& Soper (1976). Deposition started with Early Carboniferous flood plain sediments in the south-easternmost basin preserved in Holm Land, which probably included the extensive deposits offshore revealed by geophysical investigations (Larsen \& Pulvertaft, 1990). In the Late Carboniferous mixed siliciclastic and carbonate shelf sedimentation occurred in both basins. By the Early Permian a widespread transgression took place and a pan-Arctic carbonate platform was formed, upon which accumulation in the northernmost rift basin continued until the Middle Triassic. In the south-east the sediments overlie crystalline Proterozoic basement, whereas farther to the north and north-west the sediments rest unconformably on Proterozoic or Lower Palaeozoic rocks.

On aerial photographs of Holm Land and Amdrup Land the basal contact against the crystalline basement is clearly visible, as is the cliff-forming base of the Foldedal Formation and the upper part of the Kim Fjelde Formation (Fig. 2).

\section{Mesozoic and Early Tertiary sedimentation}

From the Middle Triassic to Late Jurassic, a period with no sedimentary record, the structural scenario changed, and a strike-slip zone, named the Wandel Hav mobile belt (Håkansson \& Pedersen, 1982), developed parallel to the Trolle Land fault zone and to the Harder Fjord fault zone (fig. 3 in Håkansson \& Stemmerik, 1989). The earlier stable carbonate platform was divided into smaller fault-controlled sub-basins, which during the Late Jurassic to Early Paleocene accumulated marine siliciclastic and carbonate sediments characterised by repeated phases of transgression and regression. Sediments from this period are preserved only in the area north of latitude $81^{\circ} \mathrm{N}$.

Three main structural events have been recognised within the Wandel Hav mobile belt (Fig. 2): a Middle Jurassic(?) transtensional to extensional event (Ingeborg), a Middle to Late Cretaceous transtensional event (Kilen) with formation of pull-apart basins, and finally towards the end of the Cretaceous the Kronprins Christian Land strike-slip orogeny which severely deformed the pullapart basins and led to the development of dome structures. The latter are clearly visible on the aerial photographs covering north-eastern Amdrup Land.

The youngest sediments recorded in eastern North Greenland are Paleocene (to possibly Eocene) humid fan deposits confined to grabens and half-grabens on the islands north of Ingeborg Halvø (Fig. 1; Håkansson, 1988).

\section{3 reconnaissance field work}

The short 1993 field season (5 weeks) was used for a variety of reconnaissance studies, to gain an insight into the geological problems of the region so that the comprehensive field investigations of 1994-95 could be better focused. The authors of this article formed two field teams. One team (JCE \& JDF) undertook an E-W traverse of the crystalline and sedimentary rock units of Lambert Land. The second team (HFJ \& AKH) studied some of the Caledonian nappe units of Kronprins Christian Land and made a brief visit to the foreland areas at the head of Danmark Fjord. Brief notes on the most significant observations are given below.

\section{Lambert Land - crystalline rocks}

Crystalline rocks make up the eastern half of Lambert Land (Fig. 3), and include banded gneisses, orthogneisses and a variety of metasedimentary rocks. All rock types 
Fig. 3. Geological map of Lambert Land.

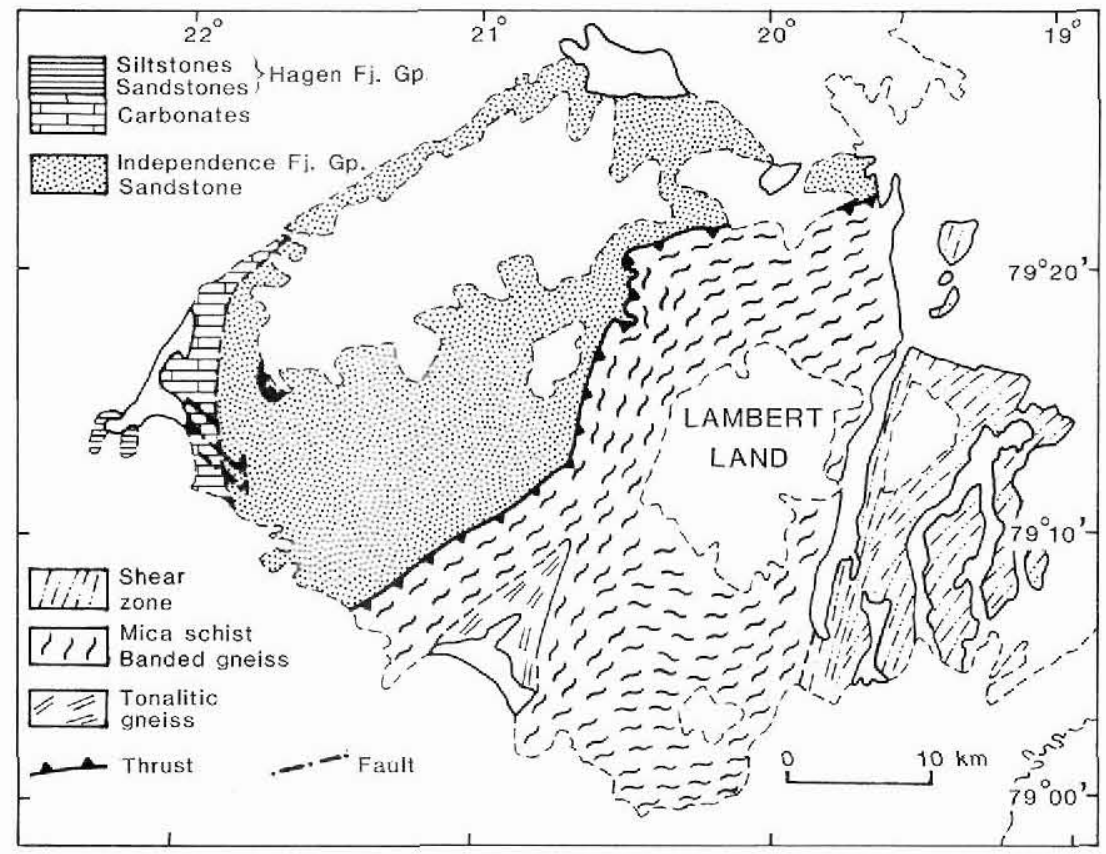

are cut by metadolerite dykes, which have provisionally been correlated with the Midsommersø Dolerites.

Schistose paragneisses are most abundant. They comprise thick bands of brown muscovite schists alternating with thinner but more massive grey, quartz-muscovite gneisses. Associated and interlayered with the paragneisses are units of quartzite and marble up to $30 \mathrm{~m}$ thick (Fig. 4), and in some cases traceable along strike for several kilometres.

The banded gneiss units consist of regular alternations of mafic dioritic to amphibolitic bands and leucocratic granitic to tonalitic bands. Occasional bands show convincing grading, and it is speculated that the alternating bands may represent acid and basic volcanic rocks. Muscovite-bearing orthogneisses locally preserve intrusive contacts with both paragneisses and banded gneisses.

Tonalitic orthogneisses in south central Lambert Land make up the structurally lowest unit of the crystalline complex; they were distinguished as 'basement' on Haller's (1983) map. They have a well developed migmatitic
Fig. 4. Distinclive marble and quartzite unit within the schistose paragneisses of eastern Lambert Land.

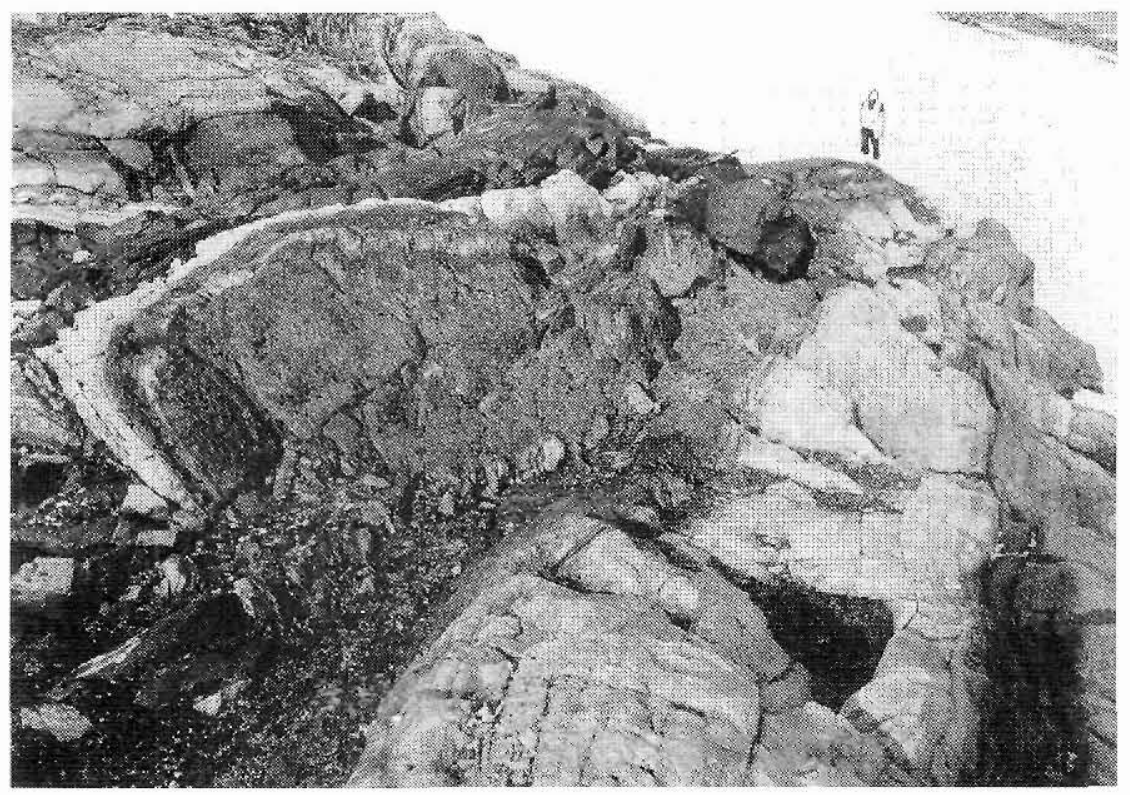




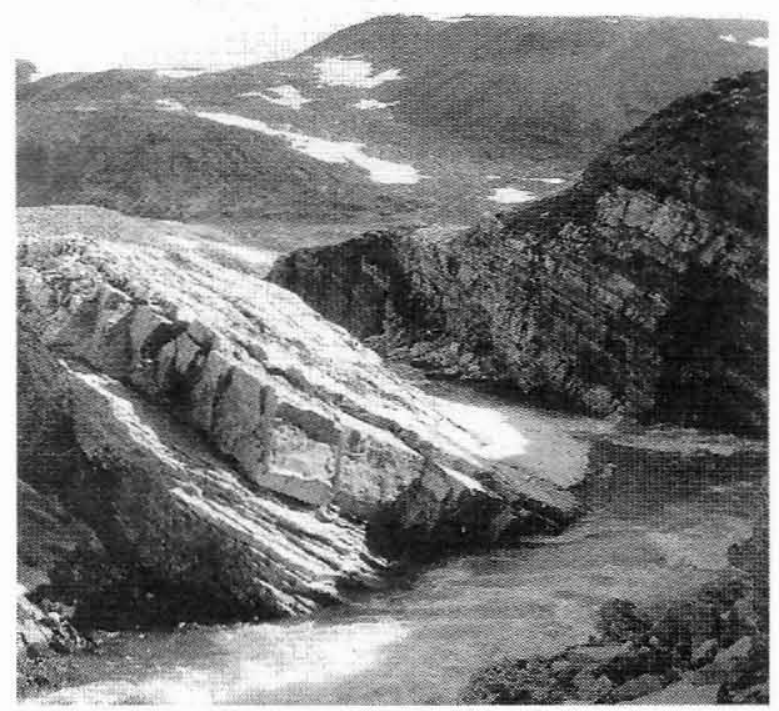

Fig. 5. South-east dipping thrust zone in central Lambert Land. Schistose paragneisses (dark rocks at right) in thrust contact with Independence Fjord Group sandstones (light coloured units). The latter are strongly sheared.

banding, and are locally cut by thin discordant pegmatitic veins.

The various crystalline rock types all show a pronounced mineral or crenulation lineation, which trends $\mathrm{E}$ to SE obliquely across the limbs of later Caledonian fold structures. Minor folds accompany the lineation but no major structures of this phase are distinguished.

\section{Lambert Land - Independence Fjord Group}

The western half of Lambert Land is dominated by the feldspathic sandstones of the Independence Fjord Group. which are in thrust contact with the crystalline rock units to the east (Fig. 5). The thrust contact is well exposed locally, NNE-SSW trending and dipping ESE at about $30^{\circ}$. Intensely sheared and mylonitic rocks form a zone several tens of metres thick, and shear sense indicators show displacement towards the north-west.

The feldspathic sandstones of the Independence Fjord Group are generally resistant to erosion, and make up the major part of the high plateau of western Lambert Land. Fresh surfaces are white, while buff to light brown weathered outcrops may show visible cross-bedding. Dolerite dykes and sills cut the sandstones everywhere, and are correlated with the Midsommersø Dolerites.

\section{Lambert Land - (?)Hagen Fjord Group}

At the western edge of Lambert Land (Fig. 3) the Independence Fjord Group is overlain by a sequence of limestones and dolomites up to $300 \mathrm{~m}$ thick, provisionally assigned to the Hagen Fjord Group; the sequence is not cut by dykes. The contact between the two successions is often affected by brittle shearing, but at a few localities primary sedimentary contacts are preserved. The lowermost limestone layers, of white pebbly limestone, appear to infill depressions in a slightly discordant surface of Independence Fjord Group sandstones.

While there is a superficial resemblance to some of the carbonate formations of the Hagen Fjord Group (Kap Bernhard Formation, Fyns Sø Formation; Clemmensen \& Jepsen, 1992), no stromatolites have yet been observed in the limestones and dolomites of Lambert Land.

Two small nunataks immediately west of Lambert Land preserve a several hundred metre sequence of monotonous shaly siltstones, overlain by a substantial thickness of alternating red spotted sandstones and shaly siltstones. The relationship with the carbonate sequence of western Lambert Land is hidden by ice, and it is uncertain whether they are equivalents of part of the Hagen Fjord Group, or part of the slightly older Rivieradal sandstone sequence.

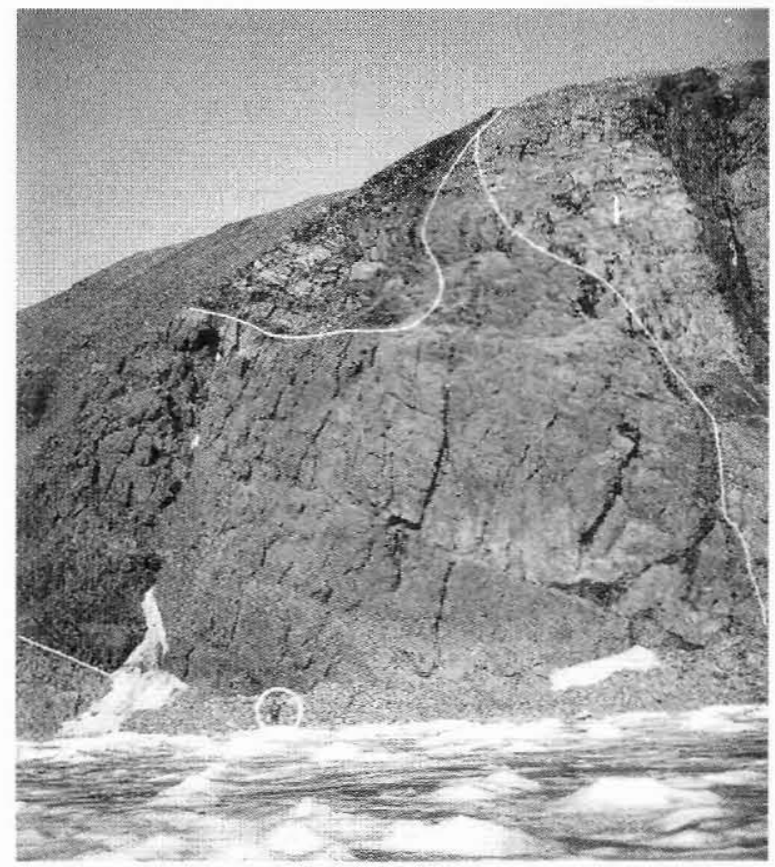

Fig. 6. Major conglomerate unit (0-60 m thick) forming spectacular fold on north side of Sæfaxi Ely. Independence Fjord Group sandstones (I) at right with metamorphosed intrusion. Pale sandstone beds and calcareous shales (?Kap Bernhard Formation) occur in core of fold. Note figure for scale. 


\section{Vandredalen - Hagen Fjord Group}

East of Vandredalen in central Kronprins Christian Land, the elongate dome-like mountainous outcrops of Proterozoic Independence Fjord Group sandstones cut by Midsommersø Dolerites (Fränkl's, 1954, 'Proterozoic swell') were known to retain a partial cover of Late Proterozoic strata at Marmorvigen (Fränkl, 1954, 1955) and at Hjørnegletscher (Jepsen \& Kalsbeek, 1981). In both cases the cover sequence begins with a conglomerate, and at Hjørnegletscher it passes up into stromatolitic dolomites of the Fyns Sø Formation.

In 1993 basal conglomerates overlying the Independence Fjord Group sandstones were recorded at two further localities on the north-east side of Sæfaxi Elv. In one case a $35 \mathrm{~m}$ thick conglomerate was overlain by about 35 $\mathrm{m}$ of sandstones and shales. In the second case a $0-60 \mathrm{~m}$ thick conglomerate unit, spectacularly folded together with its underlying Proterozoic sandstone basement (Fig. 6), is overlain by a thick unit of red calcareous shale (?Kap Bernhard Formation), which appears in turn to be overlain by yellow weathering carbonates of the Fyns $S \varnothing$ Formation.

Conglomerates are not continuously exposed along the west margin of the dome-like outcrop of Independence Fjord Group sandstones, and at several localities flatlying Fyns $S ø$ Formation strata appear to be in direct contact with steeply dipping quartzites, a contact depicted by Hurst $\&$ McKerrow $(1981,1985)$ as a thrust. The lithological contrast between the massive sandstone 'basement' and the more varied lithologies of the Hagen Fjord Group 'cover' is no doubt sufficient to produce minor dislocations with thrust sense of displacement as a consequence of Caledonian deformation.

\section{Vandredalen - the 'Safaxi Elv nappe'}

Vandredalen between inner Ingolf Fjord and Marmorvigen preserves outcrops of two distinct sequences, on the east side the units of the Hagen Fjord Group described above, and over much of the remainder of the valley Ordovician-Silurian carbonates which Hurst \& McKerrow $(1981,1985)$ placed in their 'Sæfaxi Elv nappe' and named the Harefjeld Formation (Hurst, 1984). The contact between the Hagen Fjord Group units and the Harefjeld Formation carbonates was mapped as a thrust.

Our 1993 observations at several localities near Sæfaxi Elv show the Harefjeld Formation disconformably overlying the Fyns $\mathbf{S} \varnothing$ Formation. Close to the contact fissures in the eroded top of the Fyns Sø Formation were infilled by sandstone, although we failed to find the locality where Fränkl (1955) indicated an up to $2 \mathrm{~m}$ thick sandstone unit at the contact. The disconformity surface may mark a hiatus of as much as 200 Ma. Fränkl's (1955) depictions of lithological boundaries in the vicinity of Sæfaxi Elv are more reliable than those of Hurst \& McKerrow.

The Harefjeld Formation and the underlying formations of the Hagen Fjord Group are not separated by a thrust, but appear to be part of the same 'cover' succession which enveloped the 'Proterozoic swell' to the east. Any westward displacement during Caledonian thrusting is likely to have involved both the Late Proterozoic 'cover' as well as the Middle Proterozoic 'basement' sandstones in the same nappe unit; the concept of the 'Sæfaxi Elv nappe' as defined by Hurst \& McKerrow may require substantial revision.

The broad valley of Vandredalen may conceal the original relationships between the deeper shelf facies of the Harefjeld Formation and the equivalent Palaeozoic platform sequence to the west. If the original edge of the Palaeozoic platform was close to its present outcrop limit along the west side of Vandredalen, it may be unnecessary to invoke major relative displacement of the Harefjeld Formation on a separate nappe. The precise age of the Harefjeld Formation is at present uncertain.

\section{Southern Kronprins Christian Land - Rivieradal sandstones}

The Rivieradal sandstones are a widespread thick sequence of siliciclastic sediments preserved only in the Vandredalen nappe (Fränkl's, 1954 'main nappe'). As the sequence passes up into recognisable units of the Hagen Fjord Group, it has been viewed as the possible deepwater equivalents of lower formations of the group (cf. Clemmensen \& Jepsen, 1992).

The upper parts of the Rivieradal sandstone sequence were examined in sections on the west side of Vandredalen, and deeper levels in south-east Skallingen near Kap Bernhoft. While there may be some logic in Hurst \& McKerrow's (1981) grouping of all Fränkl's (1955) lithological units into a single flych or turbidite succession, Fränkl's units remain potentially useful mapping divisions. West of Kap Bernhoft we encountered a clear continuation of Fränkl's (1955) 'Sydvejdal marbles'. West of this carbonate-rich division a conspicuous grey quartzite unit forms another useful marker.

The most significant change in our interpretation of the Rivieradal sandstone sequence concerns its upper boundary. Previously the sequence had been considered to close with a conspicuous resedimented boulder conglomerate (Fig. 7; Fränkl's, 1954 'Ulvebjerg sandstones and tillites'), the overlying clastic sequences being provisionally equated with lower formations of the Hagen Fjord Group known from the platform area (Jyske Ås Forma- 


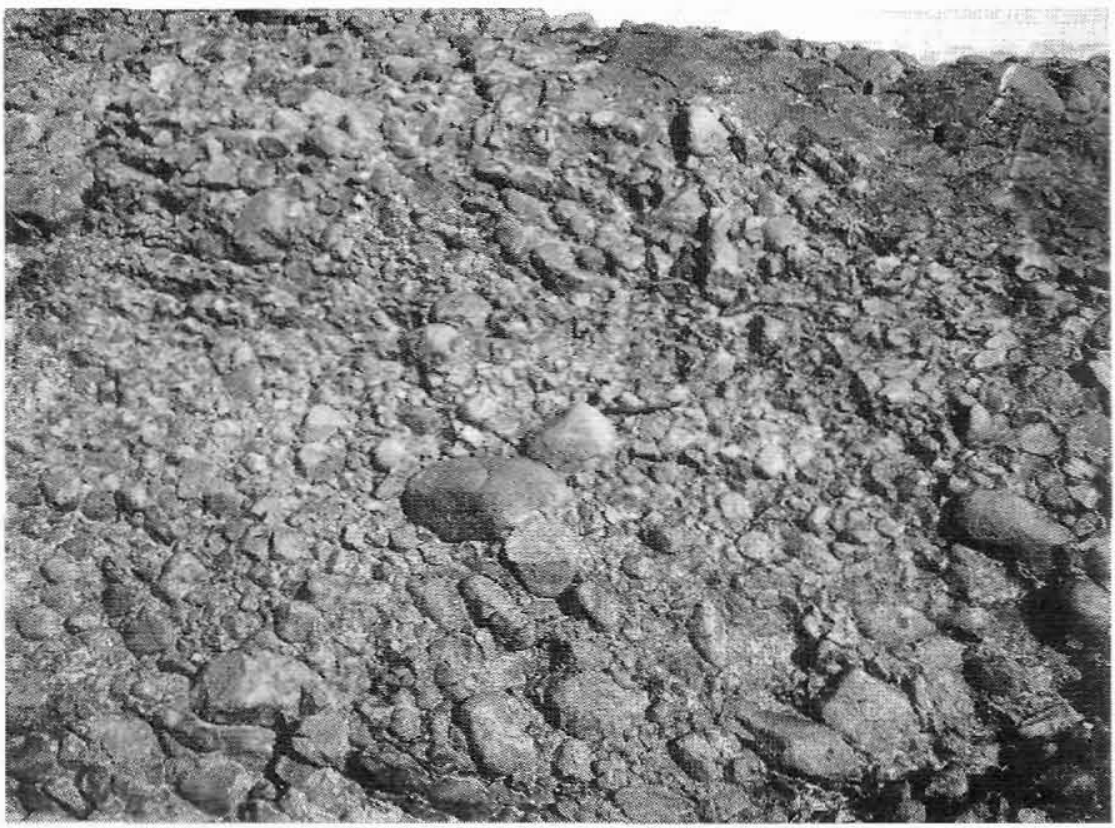

Fig. 7. The prominent boulder conglomerate in the upper part of the Rivieradal sandstones; pen $(13 \mathrm{~cm})$ for scale, west side of Vandredalen. The conglomerate is dominated by well rounded clasts of Independence Fjord Group sandstones.

tion, Campanuladal Formation; Clemmensen \& Jepsen, 1992). However, the 1993 observations of the clastic sequence overlying the conglomerate unit suggest a continuation of the sedimentation typical of the Rivieradal sandstones. We are now inclined to place the upper boundary of the Rivieradal sandstones at the change from clastic to carbonate sedimentation, that is to say at the base of the red-weathering carbonates of the Kap Bernhard Formation.

The abundance of shallow water ripple marked surfaces, and the absence of typical bouma cycles and load casts in the upper sections of the succession, cast some question on the interpretation of the Rivieradal sandstones as a single deep-water turbidite succession.

The similarity in boulder size and boulder composition of the resedimented conglomerates (Fig. 7) in the Rivieradal sandstones and the fluvial conglomerates at the base of the Hagen Fjord Group overlying the denuded Independence Fjord Group sandstones is striking, and may indicate a close relationship.

\section{Continuation of the Storstrommen shear zone}

Photogeological studies prior to the summer field season demonstrated the extension throughout the region $78^{\circ}-81^{\circ} \mathrm{N}$ of a prominent NNE-SSW trending linear belt, interpreted as the northward continuation of the Storstrømmen shear zone (cf. speculations of Holdsworth \& Strachan (1991), Larsen \& Bengaard (1991) and Strachan et al., (1992)). In 1993 this linear belt was investigated in three areas, eastern Lambert Land, the south coast of Hovgaard $\varnothing$ and the south side of central Ingolf Fjord.

In Lambert Land intensely sheared crystalline rocks outcrop in a zone more than $13 \mathrm{~km}$ wide; the east limit of the zone is not seen. Deformation intensity varies, and in low strain areas it is clear that the protolith comprises banded gneiss and migmatitic gneiss units. Lenses of amphibolite 1-10 $\mathrm{m}$ long in the sheared gneisses represent relicts of basic dykes, and contain garnets which overgrow the deformation fabric. Sheets of light grey granite up to $50 \mathrm{~m}$ thick occur within the shear zone, but are foliated only in their marginal parts and may be late tectonic (Caledonian) intrusions. Occasional two-pyroxene mafic pods are also present, but it is uncertain whether they have any relationship to the eclogite province south of latitude $78^{\circ} \mathrm{N}$. The shear zone is dominated by phyllonitic gneisses, with mylonite and ultramylonite units up to a few metres thick developed in most places. Foliation is generally near vertical, while lineations plunge southwards at $0^{\circ}-40^{\circ}$. Shear sense is dominantly sinistral.

In eastern Kronprins Christian Land the linear belt coincides with the boundary between crystalline rocks in the east (generally poorly exposed) and the Independence Fjord Group sandstones and Midsommersø Dolerites forming the alpine terrain to the west. As the shear zone is approached from the west, it is particularly striking how the random orientation of the Midsommersø dolerites is gradually transposed into a pronounced linear trend; dark NNE-SSW trending sheared dykes alternate with pale sheared quartzite (Fig. 8). South of Ingolf Fjord 


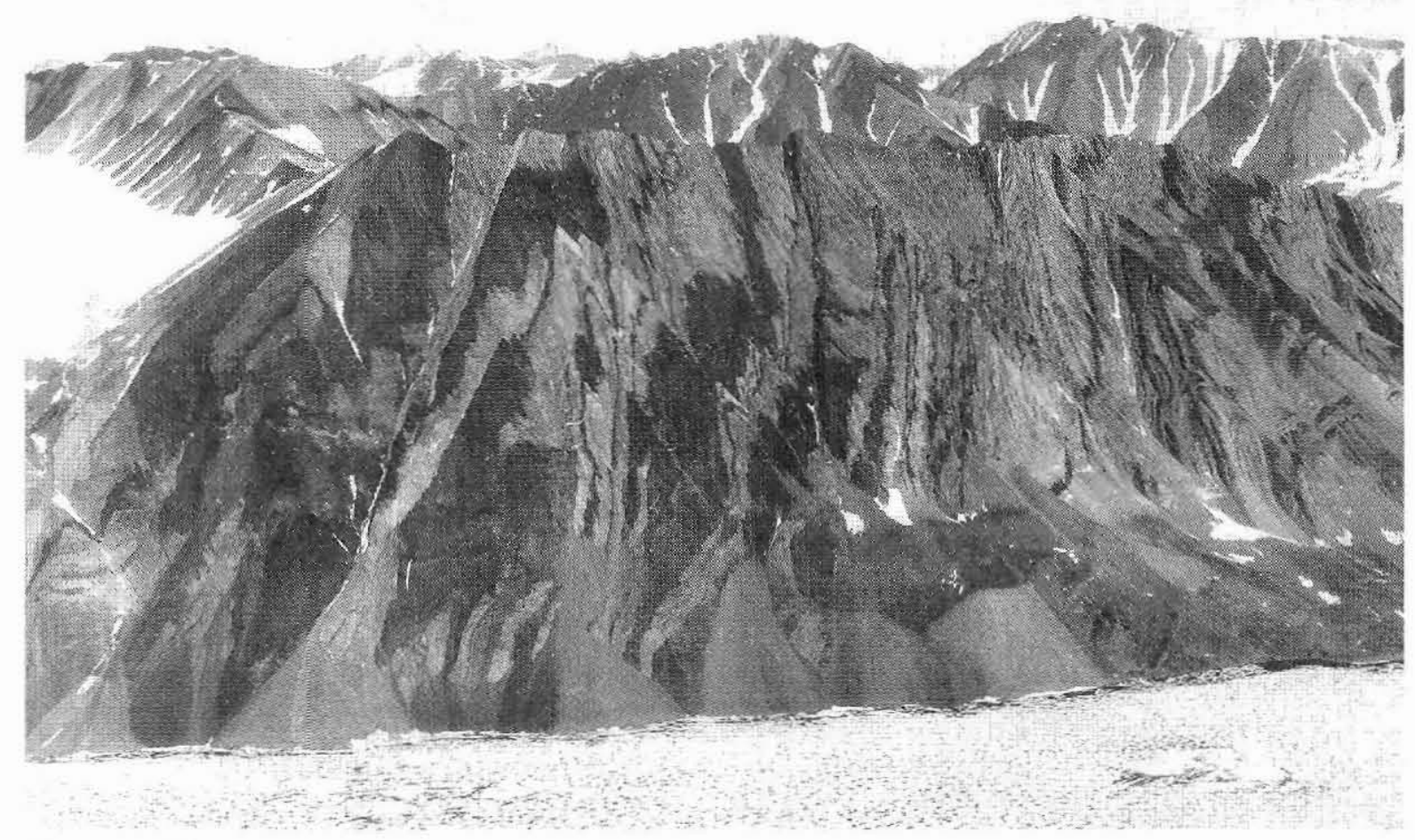

Fig. 8. Part of Storstrømmen shear zone in eastern Kronprins Christian Land, formed by strongly sheared Independence Fjord Group sandstones and Midsommersø Dolerites.

the sheared quartzites are transformed into quartz phyllites with a cataclastic or mylonitic appearance. Metadolerites are sheared at the margins and transformed into low grade greenschists, and large metadolerites are often boudinaged.

\section{Danmark Fjord - Proterozoic platform}

West of Danmark Fjord in the foreland to the Caledonian fold belt, Middle Proterozoic and Upper Proterozoic sequences are widely exposed. Around Campanuladal the Independence Fjord Group feldspathic sandstones (Collinson, 1980) are intruded by the Midsommersø Dolerites and overlain by the contemporaneous Zig-Zag Dal Basalt Formation (Kalsbeek \& Jepsen, 1983, 1984). Prior to deposition of the Late Proterozoic Hagen Fjord Group the area was peneplained, and eastwards an increasing part of the basalt sequence was removed by erosion.

The 1993 fieldwork demonstrated that the Zig-Zag Dal Basalt Formation completely disappears in the vicinity of Skjoldungeelv, where Hagen Fjord Group sediments appear to rest directly on an eroded surface of the Independence Fjord Group; however, the contact itself has not been seen. The basalt formation reappears in the alpine region around Hekla Sund, $100 \mathrm{~km}$ east of Skjoldungeelv, and this implies that the intervening area must have been uplifted prior to deposition of the Hagen Fjord Group; a substantial thickness of the Independence Fjord Group may also have been removed by erosion in this area in addition to the basalts.

\section{Future work}

The principal field work of the 1:500 000 mapping project in North-East and eastern North Greenland $\left(78^{\circ}-\right.$ $81^{\circ} \mathrm{N}$ ) will take place in 1994 and 1995 (Henriksen, 1994). In addition to their mapping commitments, all of the geological teams involved are expected to contribute information relevent to the unresolved problems of the geological evolution of the north-eastern corner of Greenland.

The crystalline terrain which makes up the deep-seated core of the Caledonian fold belt is expected to exhibit a history of major Early Proterozoic crust formation, comparable to crystalline areas south of latitude $78^{\circ} \mathrm{N}$. However, the distribution of possible older Archaean enclaves is unknown, and uncertainties surround the degree of reactivation the rocks have suffered during Caledonian deformation and metamorphism. Of particular interest is the possible northward extension of the high pressure eclogite province known south of latitude $78^{\circ} \mathrm{N}$, which is thought to be Caledonian. 
The distribution of the various Proterozoic sedimentary sequences raises a variety of problems. The Middle Proterozoic Independence Fjord Group sandstones are known over a very extensive area of North-East and eastern North Greenland between latitudes $76^{\circ}$ and $83^{\circ} \mathrm{N}$, but do not occur in situ east of the line of the Storstrømmen shear zone south of Ingolf Fjord; this may or may not be significant. The overlying Zig-Zag Dal Basalt Formation shows the same widespread distribution, but the regional setting of this major volcanic episode and the associated Midsommers $\emptyset$ Dolerites is not clear; they clearly witness to a major rifting event or significant hot-spot activity.

The Late Proterozoic Hagen Fjord Group sediments are widespread in the foreland to the Caledonian fold belt, but are also found in Caledonian nappe sheets in Kronprins Christian Land where they overlie the partly equivalent 'turbiditic' deposits of the Rivieradal sandstones. Resolution of the relationships between the shelf and deeper water sedimentary facies, and development of models for the restoration of the Caledonian nappe sheets to their pre-orogenic setting, are inter-dependent. There remain uncertainties on a broader level between the very different developments of the Hagen Fjord Group of eastern North Greenland and the presumed coeval Eleonore Bay Supergroup of East Greenland.

The absence of Cambrian strata, probably due to uplift and erosion, hinders interpretation of Lower Palaeozoic facies boundaries. Although partly obscured by onlapping Caledonian thrust sheets, the Middle Ordovician Lower Silurian successions do suggest a N-S trending shelf-trough transition. However, it is not yet clear whether the deeper-water shelf facies of the Harefjeld Formation are parautochthonous, or have been transported for substantial distances on Caledonian thrust sheets.

Kronprins Christian Land is the only region where the marginal thrust zone of the Caledonian fold belt is well preserved. Previous workers have established the existence of several nappe sheets, but existing structural models for their emplacement are unsatisfactory. The western marginal zone has a classic thin-skinned character, but eastwards appears to pass into a region involving deeper elements of the fold belt. Differences in competence between the massive Independence Fjord Group sandstones and the more varied lithologies of the Hagen Fjord Group and Rivieradal sandstones clearly influence the style of structures formed, and there is here also the additional complication of the continuation of the Storstrømmen shear zone. Reconstruction of Proterozoic and Palaeozoic lithofacies and the modelling of balanced and realistic structural interpretations are, as noted above, inter-related problems.
The Storstrømmęn shear zone has been interpreted as a major, Caledonian, sinistral strike-slip shear zone which developed synchronously with oblique marginal thrusting (Holdsworth \& Strachan, 1991; Strachan et al., 1992). Major displacement is perhaps implied by some of the differences in development of Proterozoic sedimentary sequences on the two sides of the zone, although these may as well be a consequence of $\mathrm{E}-\mathrm{W}$ contraction by thrusting across the orogen. The great width and extreme continuity of the shear zone testifies to its importance as a structural feature, but in the areas south of latitude $78^{\circ}$ so far studied in detail a lack of suitable markers means that the amount of lateral displacement cannot be demonstrated. New insights into its significance are to be expected from studies of outcrops where the shear zone cuts the crystalline terrain of eastern Lambert Land as well as where it cuts the higher level Proterozoic rocks of eastern Kronprins Christian Land.

Within the map area Wandel Sea Basin sediments have a limited distribution, and the disturbances associated with the Wandel Hav strike-slip mobile belt are essentially in areas north of the map sheet boundary. However, further studies of the sediments in Amdrup Land in 1993 revealed an unexpected hiatus within the Kim Fjelde Formation (Lars Stemmerik, personal communication, 1993). The main studies in 1994 will be carried out in co-operation with the Bundesanstalt für Geowissenschaften und Rohstoffe, Hannover, as part of a project correlating Late Mesozoic to Early Tertiary structural events in Spitzbergen and Greenland.

\section{References}

Chadwick, B. \& Friend, C. R. L. 1991: The high-grade gneisses in the south-west of Dove Bugt: an old gneiss complex in a deep part of the Caledonides of North-East Greenland. Rapp. Gronlands geol. Unders. 152, 103-111.

Clemmensen, L. B. \& Jepsen, H. F. 1992: Lithostratigraphy and geological setting of Upper Proterozoic shoreline-shelf deposits, Hagen Fjord Group, eastern North Greenland. Rapp. Gronlands geol. Unders. 157, 27 pp.

Collinson, J. D. 1980: Stratigraphy of the Independence Fjord Group (Proterozoic) of eastern North Greenland. Rapp. Gronlands geol. Unders. 99, 7-23.

Dallmeyer, R. D., Strachan, R. A. \& Henriksen, N. 1994: ${ }^{40} \mathrm{Ar} /{ }^{39} \mathrm{Ar}$ mineral age record in NE Greenland - implications for tectonic evolution of the North Atlantic Caledonides. $J$. geol. Soc. Lond. 151, 615-628.

Dawes, P. R. \& Soper, N. J. 1973: Pre-Quaternary history of North Greenland. Mem. Amer. Ass. Petrol. Geol. 19, $117-$ 134.

Fränkl, E. 1954: Vorläufige Mitteilung über die Geologie von Kronprins Christians Land (NE-Grönland, zwischen $80^{\circ}$ $81^{\circ} \mathrm{N}$ und $\left.19^{\circ}-23^{\circ} \mathrm{W}\right)$. Meddr Grønland 116(2), $85 \mathrm{pp}$.

Fränkl, E. 1955: Weitere Beiträge zur Geologie von Kronprins 
Christian Land (NE-Grönland, zwischen $80^{\circ}$ und $80^{\circ} 30^{\circ} \mathrm{N}$ ) Meddr Grønland 103(7), $35 \mathrm{pp}$.

Gilotti, J. A. 1993: Discovery of a medium-temperature eclogite province in the Caledonides of North-East Greenland. Geology 21, 523-526.

Håkansson, E. 1988: Did Tertiary compressional tectonics affect North Greenland? Summary of the evidence. Norsk Polarinstitutt Rapp., 46, 101-104.

Håkansson, E. \& Pedersen, S. A. S. 1982: Late Paleozoic to Tertiary tectonic evolution of the continental margin in North Greenland. In Embry, A. F. \& Balkwill, H. R. (ed.) Arctic geology and geophysics. Mem. Can. Soc. Petrol. Geol. 8, 331-348.

Håkansson, E. \& Stemmerik, L. 1989: Wandel Sea basin - a new synthesis of the late Paleozoic to Tertiary accumulation in North Greenland. Geology 17, 683-686.

Haller, J. 1971: Geology of the East Greenland Caledonides, 413 pp. London: Interscience.

Haller, J. 1983: Geological map of Northeast Greenland $75^{\circ}$ $82^{\circ}$ N. Lat. 1:1,000,000. Meddr Grønland 200(5), 22 pp.

Haller, J. \& Kulp, J. L. 1962: Absolute age determinations in East Greenland. Meddr Grønland 171(1), 77 pp.

Henriksen, N. 1992: Geological map of Greenland 1:500 000. Descriptive text. Nyeboe Land, sheet 7. Peary Land, sheet 8 , 40 pp. Copenhagen: Grønlands Geologiske Unders $\emptyset$ gelse.

Henriksen, N. 1994: Eastern North Greenland 1993-1995 - a new 1:500 000 mapping project. Rapp. Gronlands geol. Unders. 160, 47-51.

Higgins, A. K., Ineson, J. R., Peel, J. S., Surlyk, F. \& Sønderholm, M. 1991: Lower Palaeozoic Franklinian Basin of North Greenland. In Peel, J. S. \& Sønderholm, M. (ed.) Sedimentary basins of North Greenland. Bull. Grønlands geol. Unders. 160, 71-139.

Holdsworth, R. E. \& Strachan, R. A. 1991: Interlinked system of ductile strike-slip and thrusting formed by Caledonian sinistral transpression in northeastern Greenland. Geology 19, 510-513

Hougaard, G., Jepsen, H. F. \& Neve, J. K. 1991: GGU's photogeological laboratory: aerial photogrammetry - a valuable geological mapping tool in Greenland. Rapp. Gronlands geol. Unders. 152, 32-35.

Hurst, J. M. 1984: Upper Ordovician and Silurian carbonate shelf stratigraphy, facies and evolution, eastern North Greenland. Bull. Gronlands geol. Unders. 148, $73 \mathrm{pp}$.

Hurst, J. M. \& McKerrow, W. S. 1981: The Caledonian nappes of eastern North Greenland. Nature, Lond. 290, 772-774.

Hurst, J. M. \& Mckerrow, W. S. 1985: Origin of the Caledonian nappes of eastern North Greenland. In Gee, D. G. \& Sturt, B. A. (ed.) The Caledonide Orogen: Scandinavia and related areas, 1065-1069. London: Wiley \& Sons.

Hurst, J. M., McKerrow, W. S., Soper, N. J. \& Surlyk, F. 1983: The relationship between Caledonian nappe tectonics and Silurian turbidite deposition in North Greenland. J. geol. Soc. Lond. 140, 123-131.
Jackson, G. D. \& Iannelli, T. R. 1981: Rift-related cyclic sedimentation in the Neohelikian Borden Basin, northern Baffin Island. In Campbell, F. H. A. (ed.) Proterozoic basins of Canada. Geol. Surv. Can. Paper 81-10, 269-302.

Jepsen, H. F. \& Kalsbeek, F. 1981: Non-existence of the Carolinidian Orogeny in the Prinsesse Caroline-Mathilde Alper of Kronprins Christian Land, eastern North Greenland. Rapp. Gronlands geol. Unders. 106, 7-14.

Kalsbeek, F. \& Jepsen, H. F. 1980: Preliminary Rb-Sr isotope evidence on the age and metamorphic history of the North Greenland crystalline basement. Rapp. Gronlands geol. Unders. 99, 107-110.

Kalsbeek, F. \& Jepsen, H. F. 1983: The Midsommers $\varnothing$ Dolerites and associated intrusions in the Proterozoic platform of eastern North Greenland - a study of the interaction between intrusive basic magma and sialic crust. J. Petrol. 24, 605-634.

Kalsbeek, F. \& Jepsen, H. F. 1984: The late Proterozoic Zig-Zag Dal Basalt Formation of eastern North Greenland. J. Petrol. 25, 644-664.

Kalsbeek, F., Nutman, A. P. \& Taylor, P. N. 1993: Palaeoproterozoic basement province in the Caledonian fold belt of North-East Greenland. Precambrian Res. 63, 163-178.

Larsen, H. C. \& Pulvertaft, T. C. R. 1990: Regional marine seismic reconnaissance. Rapp. Grønlands geol. Unders. 148, 32-34.

Larsen, P.-H. \& Bengaard, H.-J. 1991. Devonian basin initiation in East Greenland: a result of sinistral wrench faulting and Caledonian extensional collapse. J. geol. Soc. Lond. 148, 355-368.

Peel, J. S. \& Smith, M. P. 1988: The Wandel Valley Formation (Early-Middle Ordovician) of North Greenland and its correlatives. Rapp. Grønlands geol. Unders. 137, 61-92.

Peel, J. S., Ineson, J. R., Lane, P. D. \& Amstrong, H. A. 1981: Lower Palaeozoic stratigraphy around Danmark Fjord, eastern North Greenland. Rapp. Gronlands geol. Unders. 106, 21-27.

Sønderholm, M. \& Jepsen, H. F. 1991: Proterozoic basins of North Greenland. In Peel, J. S. \& Sønderholm, M. (ed.) Sedimentary basins of North Greenland. Bull. Grønlands geol. Unders: 160, 49-69.

Steiger, R. H., Harnik-Soptrajanova, G., Zimmerman, E. \& Henriksen, N. 1976: Isotopic age and metamorphic history of the banded gneiss at Danmarkshavn, East Greenland. Contr. Mineral. Petrol. 57, 1-24.

Stemmerik, L. \& Håkansson, E. 1989: Stratigraphy and depositional history of the Upper Palaeozoic and Triassic sediments in the Wandel Sea Basin, central and eastern North Greenland. Rapp. Grønlands geol. Unders. 143, 21-45.

Strachan, R. A., Holdsworth, R. E., Friderichsen, J. D. \& Jepsen, H. F. 1992: Regional Caledonian structure within an oblique convergence zone, Dronning Louise Land, NE Greenland. $J$. geol. Soc. Lond. 149, 359-371. 